\title{
Power in the Workplace, Finding an Alternative to the Iron Fist
}

\author{
Oroszi Terry \\ Department of Pharmacology \& Toxicology, Boonshoft School of Medicine, Wright State University, Fairborn, USA \\ Email: terry.oroszi@wright.edu
}

How to cite this paper: Terry, O. (2020). Power in the Workplace, Finding an Alternative to the Iron Fist. Open Journal of Leadership, 9, 97-112.

https://doi.org/10.4236/ojl.2020.92007

Received: March 26, 2020

Accepted: May 24, 2020

Published: May 27, 2020

Copyright $\odot 2020$ by author(s) and Scientific Research Publishing Inc. This work is licensed under the Creative Commons Attribution International License (CC BY 4.0).

http://creativecommons.org/licenses/by/4.0/

\begin{abstract}
The application of power by leaders to achieve their goals is not novel. Leaders have exercised power for thousands of years. Regrettably, the prevailing thought is that all people using power are prevaricators, disingenuous individuals willing to slander or denigrate the people in their way. The aim of this paper is to contradict this reputation by examining the use of power in all aspects of the organization, including groups, structure, and human interaction. This paper will identify techniques or skills that the leader, through the use of power, can offer positive contributions to the organization (Carlsen, Clegg, Pitsis, \& Mortensen, 2020). When successfully employed power can be a mechanism to aid in communication, motivation to encourage growth and development of others, inspire problem-solving, and be a catalyst for change. To implement power in a constructive way, the leader or group manager must know their audience. The successful utilization of power requires emotional intelligence (EI) skills. Leaders need the capacity to reframe, to see the issues from another point of view and to analyze a situation. The leader must determine what leadership method will work for a given circumstance or individual. They must know what motivates the individual to achieve, be it the need for achievement, positive affirmation, or routine.
\end{abstract}

\section{Keywords}

Change, Communication, Leaders, Leadership, Organizations, Power, Problem-Solving, Power Bases

\section{Introduction}

In discussions on the concept of power, the benefits of its use are often controversial and seldom perceived as positive. Throughout history leaders that wielded power were seen as greedy, corrupt, and self-indulgent, leading us to the perception today that desiring or using power is bad (Krausz, 1986). This paper 
illustrates how power can be used in organizations to achieve the goals of the organization. When employed in a productive and positive manner power can improve communications, motivate employees, and improve organizational group efficiency. One persistent problem for leaders is to get others to do what is required to accomplish the goals of the organization. Leaders with an understanding of organizational power bases can effectively use their power to influence others and achieve those objectives (Michelson, 2010).

The perception in organizations regarding the use of power is negative. There is a dark side of power, and typically those that use power in this manner do so at a cost to others. Using power in an organization is frowned upon, with a perception that using power is bad, and lacks benefits to the organization. To show that power can be employed in a positive way to motive, communicate, and problem solve (Carlsen, Clegg, Pitsis, \& Mortensen, 2020). To identify methods a leader can use to accomplish these goals (Munduate \& Medina, 2017). To introduce to the leader tools to self-reflect because to know oneself will generate better leaders. The purpose of this research into organizations and power is to inform the leader of ways power can be applied to improve organizations. This paper will explain how a leader can use power in a positive way (de Andreis \& Carioni, 2019). It will give examples of methods a leader can use power to improve the motivation of employees, work in productive groups, and achieve the goals of the organization such as implementing change and creating a work culture (Carlsen, Clegg, Pitsis, \& Mortensen, 2020).

\section{Operational Definition of Commonly Used Terms}

Power. Power is the ability to influence or impose one's will upon others to control their actions, to get others to do something that they would not otherwise do (Berko, Rosenfeld, \& Samovar, 1997; de Andreis \& Carioni, 2019; DeVito, 2010; Ocasio, Pozner, \& Milner, 2020; Weber, 1946).

Communications. As defined by the (Communications, 2015), "Communication is a process by which information is exchanged between individuals through a common system of symbols, signs, or behavior".

Leader. Etzioni (1961) uses the term leader to refer to those "who possess personal power, either formally or informally".

Leadership. Leadership is defined as "Interpersonal influence, exercised in a situation and directed through the communication process, toward the fulfillment of a specific goal or goals" as defined by Tannenbaum (1962) and (Hersey \& Blanchard, 1969).

\section{Review of the Literature}

\subsection{Power}

This review will provide a deep dive into power. Starting with a historical perspective, its use in organizations by their leadership and within groups, it will provide the reader with the tools to use power to improve their organizations. 


\subsection{A Brief Historical Perspective on Power}

Power has been an effective tool used by leaders for thousands of years. Historical figures are still admired or admonished based on their use of power. The word Machiavellian has become synonymous with a leader who is a clever, cunning and duplicitous wielder of power. Machiavelli's voice represented reality, and not the idealized version of a Prince, which was unheard of in the $1500 \mathrm{~s}$ (Machiavelli \& Mansfield, 1998). Machiavelli lived in a time when power derived from the capacity to do violence. The more subtle models of power discussed by authors of the last century might have made little sense to him, and make sense only in our modern, democratic, egalitarian society. Leaders with power are respected; however, history teaches us that the wielding of power is not always advantageous. Burns (1978) spoke of our continued interest in historical leaders like Stalin and Hitler. He pointed out that although power can bring with it evil and brutality, it can also be exercised to develop positive relationships that improve the communication exchange, as well as influence others, and encourage leadership.

\subsection{Power in Organizations}

Organizations are created to achieve a goal; the employees are hired to make the vision a reality. Leaders within the organization can use power is a positive way to accomplish goals (Michelson, 2010; Munduate \& Medina, 2017). In fact, power is essential at every level within an organization and competition for power is a part of business as well (Zaleznik, 1970). The use of power in an organization can require political skills and an understanding of others points of view. One must understand the game, and the players (Pfeffer, 1992). In a study by Murray and Gandz (1980), 93\% of organizational managers agree that workplace politics/power exist in their organizations, and $70 \%$ felt that leaders must have power to accomplish their goals. When asked if power should exist in the organizational arena, many responders said no. They agree it is there and necessary but prefer otherwise.

Today organizational leaders are often in the spotlight. They are under a media lens and scrutinized for every action they take. The need for the organizational leaders to interact with others outside of their industry has never been so necessary. The organization is not a closed system, to accomplish goals, such as needed supplies, distribution and selling of products they must work effectively with others. When an organization maintains effective interactions with the community, it has the power to be more selective with the vendors, and a positive public persona will increase their power.

Power in organizations is disseminated among its members, and the distribution of the power determines the power structure of the organization. Pyramidal and flat are two examples of power structures, the former a hierarchical structure focusing power at the top, the latter distributing power evenly among the members (Krausz, 1986). The pyramidal or hierarchical power structures are not always preferred. In fact, some organizations attempt to remove power. Some large organizations attempt to disperse power by creating subunits or depart- 
ments, but this creates communication problems, particularly when subunits must cooperate to accomplish a goal (Lawrence \& Lorsch, 1967). The organization is once confronted with the coordination of the subunits to achieve implementation.

Goal-based bureaucracy removes power from the workforce. When early management theorist, Weber (1946), shed light on bureaucracy and the bureaucratic approach, he was talking about a monocratically organized system. Although there is a hierarchy, the positions are task driven, not power driven. $\mathrm{Bu}$ reaucracy attempts to eliminate the use of power in the course of attaining organizational goals.

\subsection{Power in Organizational Groups}

Studying the nature and behavior of groups is a field in its own right. Cartwright and Zander (1968) defined group dynamics, relationships within the groups, and relationships with the environment. Groups within an organization can be formal or informal. Formal groups are created to perform a task, like problem-solving, decision-making, or to achieve a particular goal (Schein, 1977). When a group is working well together, all of their knowledge is pooled, thus increasing problem-solving outcomes (Maier \& Hoffman, 1960). Acceptance of decisions is increased when the participants of the group are part of the decision making (Coch \& French Jr., 1948; Maier, 1952). The heterogeneity of the group is also important. The diversity of perspectives and experiences, as well as homogeneity of levels of power of the group participants, should be considered when forming a group.

The debate on linear versus nonlinear thinking in organizations has been circulating for several years. The classical belief is that organizations are best when operating in a linear, rational method (Stacey, 1996). Experts like Senge (1990) believe organizations are nonlinear and constantly evolve. Groves et al. (2011) found a balance of linear and nonlinear thinking in a group will be more likely to provide a nonlinear, less structured approach to problem-solving. The group leader has the power to make this successful by encouraging innovation. To think in a creative, out-of-the-box manner, the group members need to feel comfortable even if the idea is rejected. Individuals within the group will not use all the same processes to think (Page, 2008). This diversity supports nonlinear thinking in a group setting, which, if unhindered, allows a greater range of possible solutions to be considered. Nonlinear thinking in a group allows thought to flow, increasing the potential outcomes for problem solving (Vance, Groves, Paik, \& Kindler, 2007). Nonlinear thinkers often approach problems starting from an area in which they are most comfortable. This is similar to Bolman and Deals' Four Frames. If operating with a Human Resource lens rather than a Structural one, a group member may explore a different path to a solution. Where non-linear thinking fails is when the group cannot achieve consensus. Without broad support, the leader may not have the power to carry out the required actions. 
Mansfield (1998) The Prince critically assessed the politics of the day, and laid the foundation for contemporary critical thought. By improving communication and problem-solving skills with critical thinking (asking why or looking at a problem through a different frame) the leader may inspire more nonlinear thinking. Critical thinking necessitates effective communication and problem-solving abilities. The goal of critical thinking is to remove bias and egotism and from the solution and to examine critically favorable options and success in problem-solving by the group depends heavily on the leaders.

A leader wields power more efficiently when the leader shows the ability to look at problems from different perspectives. Bolman and Deal (1991) describe these organizational views in terms of four major frames: Structural, Human Resources, Symbolic, and Political. A combination of the frames may be most successful. The Structural group leader may design a process that will be appropriate to the problem and the circumstances. They will be good at identifying the group goals and keep the group on task. The Human Resource leader will be responsive to the needs and goals of the individuals within the group. The leader may try to empower the group members and be supportive. The Symbolic leader will inspire the group, they will give the group an identity and the cohesiveness to work through the problem-solving process. Group members do not always play well with each other, especially if they are struggling for power. When the Political leader manages this disruption, they will build power (Bolman \& Deal, 1991).

Bolman and Deal's (1991) reframing similarly offers the most efficient way to communicate (style and use) an idea in groups (see Table 1). Leaders do not see the world using the same lens. Someone using the structural lens enjoys fact and policies, they may use them to gain knowledge, to be the "go-to" person, to prevent from doing things incorrectly, or as a protective tool, used to hide behind when asked a question. The Human Resource lens is one of compassion, they care about their teammates, and make decisions with others in mind. The Symbolic lens is one likened to a cheerleader for the organization, they will bring people together and support the goals of the organization. Lastly, the Political lens, a person using the political frame lens may enjoy the challenge of winning people over to their side of thinking and see the process as a game. The Frames allow the communicators to develop a comprehensive picture of what others may be thinking, thus providing a powerful undetectable weapon that will heighten the development of others through skillful interactions. When a leader is communicating with someone using the Structural Frame information will be exchanged by articulating the facts exclusively. The Human Resource Frame is an exchange acknowledging the needs and the feelings of the other. When there is a need to manipulate or influence, the Political Frame is superlative. Lastly, telling stories and using images to set the tone of the conversation is relying on the Symbolic Frame. There is a relationship between power, political language and symbolism. Attitudes and beliefs, as well as social perceptions, operate collectively to affect decisions and resources (Pfeffer, 1981). 
Table 1. Four frames \& communication styles.

\begin{tabular}{|c|c|c|}
\hline Frame & Communication Style & Best used when ... \\
\hline $\begin{array}{l}\text { Political } \\
\text { Framework }\end{array}$ & Hidden agendas while conversing. & $\begin{array}{l}\text { Will be good if the conversation is } \\
\text { negotiating, try to convince the other to } \\
\text { buy into their side. }\end{array}$ \\
\hline $\begin{array}{l}\text { Human } \\
\text { Resource } \\
\text { Framework }\end{array}$ & $\begin{array}{l}\text { These leaders will communicate with } \\
\text { feeling, will listen to the other(s). }\end{array}$ & Will work and collaborate as a team. \\
\hline $\begin{array}{l}\text { Structural } \\
\text { Framework }\end{array}$ & Logical, realistic, communicate with facts. & $\begin{array}{l}\text { Will keep the conversation on task. No } \\
\text { emotions involved. Logical thinking. }\end{array}$ \\
\hline $\begin{array}{l}\text { Symbolic } \\
\text { Framework }\end{array}$ & $\begin{array}{l}\text { The conversation will be inspiring, will be } \\
\text { transparent. }\end{array}$ & $\begin{array}{l}\text { Will inspire the others, instill belief and } \\
\text { buy-in. }\end{array}$ \\
\hline
\end{tabular}

Note. Bolman and Deal's (2011) four ways to think about how leaders communicate with a different lens.

The leader must focus on the use of communication to motivate. Knowing what inspires the person the leader is trying to influence will help achieve mutual aims goals. When the goals of the leader align with the objectives of the organization, the chances of success are increased. Goal achievement is accelerated by the leader's ability to communicate, problem solve, make decisions, or simply to operate in an effective and productive manner.

Motivation falls under the category of individual processes. By looking at several motivational theories, and applying them to achieve goals leaders gain respect and increased power from their subordinates or group members. Recognizing the personal growth needs of the team is also critical to effective leadership. When basic needs are satisfied, higher order essentials, like esteem and self-actualization become more attainable (Maslow, 1943).

The leader's power to lead will be dependent on their ability to motivate. To motivate the leader must ensure job satisfaction in his/her employees. The leader must pick the right candidate(s) for the job, and then use motivational tactics to keep them performing. By doing so, the leader gains respect and has fewer barriers on the path to goals. The leader must acknowledge more than the work performance, they must use their emotional quotient (EQ) to learn more about the employee, and their personal needs. Self-respect is a need shared by many. However, strength, reputation, and independence needs are seen less frequently. With the leader's approach to these tailored to the individual an increase in motivation to perform and job satisfaction is possible (Maslow, 1943). When it comes to trust and mutual respect, Follett (1927) believed the workforce would have a positive attitude and increased motivation if shown such respect, leading to more productivity. By relinquishing power, supervisors may empower workers, giving them a sense of ownership and pride in their work output. If workers are in an incompatible position, they can become dispassionate, depressed, and display poor work performance. Dissatisfaction of employees in the organization decreases revenue and weakens a positive work culture. The motivation of the employee is imperative to imperative to the success of the organization. 
Herzberg (1966) believed there are various factors involved in generating job satisfaction and motivation. Herzberg's Two-Factor Theory identified a correlation between employee attitude and work motivation. The first factor, hygiene, describes the events that cause dissatisfaction in the work, such as job security, relationships, power and leadership in the workplace. According to Herzberg, these hygiene factors do not motivate employees. When they are absent or inadequate, hygiene factors can cause dissatisfaction. The second factor is motivators or satisfiers. These are connected to employee motivation and arise from intrinsic conditions of the job. Motivation factors include job satisfaction, achievement, recognition, opportunities for advancement and growth.

There are a number of motivational techniques available to the leader to use with their employees. The use and selection may be dependent on the individual as well as the leader. What works for one may not work for all. One such technique is the reward-based power exchange, also known as transactional leadership. The transactional leader defines instructions, ensuring clarity on expected outcomes, and requirements of their subordinates. There are rewards for achieving expected outcomes. Punishments are not always mentioned but are understood.

The need for achievement (nAch), is a motivator for a minority of people. The person that desires to achieve, or get ahead, to be happy at work, may sound like a definite industrious individual, and on the surface a team of nAch employees would seem perfect. It would be a mistake to consider the nAch trait as one always advantageous to the organization's success. The employee may have a need to achieve, but not the tools or skills to do so. If the nAch worker is in a monotonous job with no chance for promotion, a higher salary will not avert dissatisfaction (McClelland \& Burnham, 1995). It can be understood from Herzberg (1966) that salary is never a motivator; salary rests comfortably in the hygiene category.

The Hawthorne experiment suggests that by merely giving the workers' attention there is an improved output. Review of the details of the Hawthorne experiments reveals that other variables, such as close supervision, improved work conditions, and increased salary were implemented. The exclusion of additional unidentified variables does not invalidate the results of the experiment; however, identifying additional variables confirmed that a worker will be motivated to perform beyond current demands if they feel valued (Roethlisberger, 1941).

\section{The Leader in an Organization}

Leadership is a tool used to influence, encourage, or inspire others. Power is a leader's weapon that helps achieve common goals and has a bearing on the different leadership styles required to manage groups within an organization (Hersey, Blanchard, \& Natemeyer, 2001). The characteristics and behaviors of leaders may fluctuate depending on the goal or the people they are leading. Leadership style is determined by the leader's behaviors. Leadership styles are categorized by several different means. For example, an organization interested in decision 
making may define leaders as either autocratic or democratic (see Democratic leadership). Another organization may be interested in how their leaders handle diverse situations, labeling those leaders as charismatic, participative, situational, transactional, transformational, laissez-faire, or servant-like.

A platform is defined as a raised structure or a politician's policy. For this paper, the definitions are merged, and a new operational definition is given. The platform is the leader's comfort zone, their place of operations. It is a combination of their preferred frame or lens, principle power base, and leadership style. Once the leader identifies their platform, they know how much work they must do to reframe, or change, to motivate others and achieve their goals. Leaders must know themselves before they can lead others. Through the understanding of personal emotional leadership styles; they gain insight to empower themselves and in choosing a style that would be most effective with their employees. Resonant leadership is a style illustrating the power of a leader that exhibits empathy and employs the emotional intelligence to relate with the people (Golemon, Boyatzis, \& McKee, 2004). A less appealing style often witnessed in organizational meetings and conversations would be the discordant leader. This leadership style creates dissatisfaction in the workplace and illustrates the total lack of connectivity with the people. These leaders believe in the iron fist of power and wield it often without mercy. Other examples of this style include the pacesetter leader, one that may appear disconnected and excessively task orientated, not able to establish a rapport with the followers. One that leads with command is less efficient at communicating or understanding the needs of the individuals within the organization. These styles are effective on some occasions. Nevertheless, Golemon et al. (2004) warn us to use these approaches sparingly.

Many leaders misunderstand the visionary leadership style. Leaders must take the time to recognize the vision of their people, and project their vision in a voice that is motivating and achievable. Without the support of the leader's team, it is unwise for a leader to bring forth their own vision and thrust it on the people (Hesselbein \& Goldsmith, 2006).

House and Mitchell (1975) described four styles leaders often used and referred to this as the Path-Goal Theory of Leadership. The four styles are directive, participative, supportive, or achievement oriented. Directive leaders provide structure to the group, participative leaders include the group members in the problem-solving process, and supportive leaders are often seen as leaders offering support and show high emotional quotient (EQ). Achievement-oriented leaders expect excellence and set challenging goals. Leaders move their groups toward success and/or the completion of their task by tapping into various types of power.

Bases of power are tools leaders use to influence their employees. Etzioni (1961) recognized three bases of power, Coercive, Utilitarian, and Normative. A leader leads by force if operating from a Coercive power base. A Utilitarian power base leader barters with the members, compensating them for their contributions. The Normative leader is working with a group of volunteers, often 
with a shared moral agenda. Peabody (1962) identified four bases of power, Legitimate, Positional, Competent and Personal. Raven and French Jr. (1958) supported the idea of formal and informal authority when they identified five bases of power that blend well with the Peabody (1962) and Etzioni (1961). The focus of Raven and French's model is more on the social relationships and interaction of power (Warren, 1968). Their model consists of Coercive, Legitimate, Expert, Reward, and Referent power bases. The Legitimate power base is formal, and the wielder has the authority to make demands and expect compliance. Operating from the Reward power base is a transactional leadership style, the leader compensates the member for complying with his/her demands. The Expert has knowledge and skills to outperform others, and may be an informal leader rather than a formal one within the organization. This may be the person to be elected internally to be the group leader, and may be similar to Peabody's competent base. The Referent power base is one from which a well-liked and admired person can operate from, they are often seen as organizational superstars. Coercive, like Etzioni's base, is one that achieves compliance from others through the threat of punishment. The threat of punishment for lack of compliance can be part of the transactional leadership style as well. Raven \& Kruglanski (1970) added a sixth base, information, this is for the leaders that may not be the experts but have done the research required and have the information needed. Hersey and Goldsmith (Tworoger \& Preziosi, 2004) identified a seventh, Connection. The person with the connection base can illicit compliance or support from others that want the connection or networking that this power base user owns.

Mansfield (1998) understood the importance of informal or personal power. When he asked is it better to be loved (personal) or feared (positional) he was stating that personal power (love) will increase your influence, but can be fleeting, fear is more enduring. Positional, like formal, power comes by rank or title. Using positional power, as the Coercive power base, can hurt more than help (Chiang, 2009). Personal power is reflected in the treatment and respect shown to employees and customers, as Follett pointed out almost 100 years ago, show them respect and they will perform (Follett, 1927). Take away respect and treat the employees like cogs, implementing Taylorism and his Scientific Management theory, and performance/job satisfaction will plummet (Gilbreth, 1912).

\section{Applying the Skills: Change in Organizations}

Generating ideas within organizations is quite easy; however, having the skill to sell, fight for, or execute the ideas within the organization, or across organizational boundaries, is typically where the ideas fail. The skills to implement require power and influence (Pfeffer, 1992). Most people resist change, even when the change is clearly beneficial to the organization. Change will happen. It is essential for the organization to forecast potential events and adjust their strategies to stay in business. 
When a business does not prepare its employees for change, the environment can become a battleground, costing the employer money, production, and in some cases the business itself. Creating subunits or departments does not only disperse power, but it is also a method for an organization to use to cope with change. A communications and marketing department will have to adjust often to keep up with new technology. Whereas a finance department will not, thus be saving resources for the more rapidly changing subunits. If a company does not react to the external change quickly enough, it will not survive. The use of subunits can make the organization more complex (Lawrence \& Lorsch, 1967). The subsystems within a large established company are often resource dependent, adding more complexity and increasing chances for failure.

Differentiation is a powerful mechanism needed for organizations to manage change. Differentiation is part of contingency theory, the organizational theory that advises the need for an organization to be mindful of internal and external factors to prepare for change. Growth-induced change in an organization's infrastructure will need to be controlled. According to Coch and French (1960) the organization can overcome resistance and inspire acceptance and eagerness for change by supporting leaders that use their power, formal or informal, to make it happen. Bolman and Deal's (Bolman \& Deal, 2011) reframing tools are also helpful when promoting change (see Table 2). Change theory experts Lewin (1939) propose two change models to guide companies through the painful change process.

The leaders in the organization may be unknowing impediments to change. Leaders may resist change or be risk-averse out of fear. The unknown can be frightening. The work culture can also hold the organization back because the initiated change may involve vast numbers of employees. The change must be supported by everyone, the top, middle, and bottom. If the change is too complex, it will not get the support needed.

Table 2. Four frames \& change.

\begin{tabular}{|c|c|c|c|}
\hline Frame & Trait/power & Use & Change incentive \\
\hline $\begin{array}{l}\text { Political } \\
\text { Framework }\end{array}$ & $\begin{array}{l}\text { Compete for power } \\
\text { and resources. }\end{array}$ & The leader builds alliances & $\begin{array}{l}\text { Encourage team building and } \\
\text { competition to achieve change } \\
\text { mini wins. }\end{array}$ \\
\hline $\begin{array}{l}\text { Human } \\
\text { Resource } \\
\text { Framework }\end{array}$ & $\begin{array}{l}\text { Extended family, } \\
\text { considers needs } \\
\text { and feelings. }\end{array}$ & $\begin{array}{l}\text { The leader empowers, } \\
\text { supports and trains. }\end{array}$ & $\begin{array}{l}\text { Develop learning tools to aid in the } \\
\text { transition. }\end{array}$ \\
\hline $\begin{array}{l}\text { Structural } \\
\text { Framework }\end{array}$ & $\begin{array}{l}\text { Goals, specialized } \\
\text { roles, formal } \\
\text { relationships. }\end{array}$ & $\begin{array}{l}\text { The leader defines goals } \\
\text { for the organization. }\end{array}$ & $\begin{array}{l}\text { Reestablish goals or small wins for } \\
\text { the change initiative. }\end{array}$ \\
\hline $\begin{array}{l}\text { Symbolic } \\
\text { Framework }\end{array}$ & $\begin{array}{l}\text { Culture, rituals, } \\
\text { stories. }\end{array}$ & The leader is a visionary. & $\begin{array}{l}\text { Create a new vision for the } \\
\text { organization. }\end{array}$ \\
\hline
\end{tabular}

Note. Bolman and Deal's (2011) Framing and reframing and leadership related to change. Four ways to think about organization and leadership. 
Kotter and Cohen (2002) understood that a leader has the power to inspire change. They identified eight steps used to encourage employees to embrace change in the organization. The first step is creating a sense of urgency; if this change does not take place something less desirable will happen. This step is essential to creating the requisite conditions essential for promoting change. The second step, team selection, reminds us of the importance of picking the right players. Determining the vision for the change and dispersing this vision is step three. Naturally, the next step, getting the support, or buy-in, from the employees is important early in the process. Step five advises that empowering the employees and removing barriers will help gain support. If short, quick wins can take place periodically, the momentum and support will continue, as identified in step six. By step seven, the urgency can dissipate if the support pauses. Kotter and Cohen (2002) tell us to remove needless work to keep the focus. At step eight the desire is to make sure the change is embedded in the work culture. The embracing of new group norms can be emotional, and the pull of the old culture will be strong. Some of these steps may need to be repeated.

Lewin (Papanek, 1973) generated one of the foundational models for understanding organizational change. In the 1950s, he introduced a model using a block of ice analogy, Unfreeze-Change-Refreeze. The first step is preparing the organization for change; the second is the change itself, and the final step, like Kotter's step eight, solidifying the change.

The organization's leaders can control change step-by-step if they see it coming, actively lead the change, with power and influence, and prevent relaxation of change initiative. With proper management of change, the evaluation of the change process can be achieved. Assessment methods include surveying employees, measuring the quality of the output pre and post-change, together with customer satisfaction, sales, finances, productivity and cost control.

Power can be advantageous when a group is trying to cope with change (Salancik \& Pfeffer, 1978). The way an organization operates today may not be the way it will operate in the future. When change is on the horizon, hiring new employees that think in a manner different from the current culture will help combat resistance to change, and inspire innovation.

\section{Applying the Skills: Organizational Work Culture}

Work culture is the personality of the organization. An organization can intentionally implement a work culture. Without the support of the employees, the culture will not propagate. In the absence of an effective leadership-sponsored culture, the workers will fill that vacuum with a culture that works for them. Companies have the power to foster a work culture that will be embraced by the organization at large. Symbols are powerful and influential tools when recruiting organizational interest in cultural development. Symbols appeal to the soul. Work culture creates unity, a feeling of belonging, and group cohesiveness when successfully implemented. Cultures evolve over time. They are a culmination of 
the people and the lessons, habits, and customs they developed. Work culture drives success and therefore should be a priority (Denison, Hooijberg, Lane, \& Lief, 2012).

Schein (1999) states that culture is comprised of three parts, the invisible under-layer that makes up the unconscious beliefs and assumptions of the organization. Second are the values. In the foreground are the artifacts, behaviors, and norms. Choosing employees with characteristics consistent with the desired culture is essential to keeping the culture alive. Although not necessarily stated in the job description, knowing the culture of the organization is important to any job seeker.

\section{Summary}

The success of the organization starts with obtainable, marketable goals. Employees will take the organization's goals and make them their own if there is motivation to do so. Employees benefit from an established work culture and a clear outline of expectations. Professional working relationships must be nourished and respected. Through the use of power, leaders can achieve all of this and more, creating a work environment that can handle change, growth, and the natural ebb and flow of organizations. People spend an average of forty hours a week in their work environment. The use of time is more efficient when the goals of all participants are aligned.

When organizations change, the distribution of power also changes. The shift of authority can be energizing and the genesis of new ideas. Knowing the motivations of the employees will ease the transition. Engaged leadership is essential for the implementation of change.

Power can assist in communication, provide motivation to encourage development and growth of others, inspire problem-solving, and be a catalyst for change. The tools needed to use power constructively are emotional intelligence skills and the capacity to reframe. The supervisor must learn what leadership method will operate for a given condition or person. This paper explored the concept that a leader or a group manager must know not only themselves and what sort of leader they represent but know their team, so they can inspire individuals, mold groups, and guide the organization.

Context and experience are critical to comprehension. Learning, growth, personal and organizational change is most active when it develops from concrete personal experience. Leaders utilizing their power will approach, mold, and revise developing theories on-the-fly. Recipients of instruction/ initiatives individually mediate what is understood, making learning a highly individual process. Effective leadership and mentoring accommodate these personal differences in their "audience".

Promoting cognitive process via engaging the emotional response of the individual is often more necessary than focus on the end-goal. Establishing openended organizational environments aimed at critically examining and cultivating 
cognitive involvement enhances understanding and garners positive response from the learner/employee/worker. Open-ended organizational environments engage participants and nurture understanding, exploration, personal ownership of new ideas.

\section{Future Research on Power}

The concept of a Leader's Power Platform could be explored in more detail. Through the use of a questionnaire and interviews, a more detailed Power Platform assessment tool could be developed and disseminated. A brief example of how it could work is explained. Leader X's Platform, Choose one (or more) of four distinctive "Frames" from which people view their world.) Structural Frame, Human Resources Frame, Political Frame, and/or Symbolic Frame. Choose one (or more) of five: (French, Raven, \& Cartwright (1959) five bases of social power) Expert power, Reward power, Legitimate power, Referent power, and Coercive power. Choose one (or more) of six: (Golemon, Boyatzis, and McKee (2004) in Primal Leadership, describe six styles of leading.) The Visionary Leader, The Coaching Leader, The Affiliative Leader, The Democratic Leader, The Pace-setting Leader, The Commanding Leader. Based on what is known about each of the Frames, power bases, and leadership styles a Power Platform could be established such as Combination: As a leader $\mathrm{X}$ is most comfortable operating on a platform where he/she is looking through a structural frame, with a social base of legitimate power, and is a democratic leader. Diagnosis: Leader X's power is positional, and he/she likes policy and rules. By choosing to be a democratic leader $\mathrm{X}$ does not need to make decisions alone. This appears to be a very safe place. He/She may not like confrontation, may not feel confident in themselves, or their power as a leader.

\section{Conflicts of Interest}

The author declares no conflicts of interest regarding the publication of this paper.

\section{References}

Berko, R. M., Rosenfeld, L. B., \& Samovar, L. A. (1997). Connecting: A Culture-Sensitive Approach to Interpersonal Communication Competency. Fort Worth, TX: Harcourt Brace College Publishers.

Bolman, L. G., \& Deal, T. E. (1991). Reframing Organizations. San Francisco, CA: Jossey-Bass Publishers.

Bolman, L. G., \& Deal, T. E. (2011). Reframing Organizations: Artistry, Choice and Leadership. New York: John Wiley \& Sons.

Burns, J. M. (1978). Leadership. New York: Harper Collins Publishers.

Carlsen, A., Clegg, S. R., Pitsis, T. S., \& Mortensen, T. F. (2020). From Ideas of Power to the Powering of Ideas in Organizations: Reflections from Follett and Foucault. European Management Journal. https://doi.org/10.1016/j.emj.2020.03.006

Cartwright, D., \& Zander, A. (1968). Power and Influence in Groups: Introduction. 
Group Dynamics: Research and Theory, 3, 215-235.

Chiang, S. (2009). Personal Power and Positional Power in a Power-Full "I": A Discourse Analysis of Doctoral Dissertation Supervision. Discourse \& Communication, 3, 255. https://doi.org/10.1177/1750481309337199

Coch, L., \& French Jr., J. R. (1948). Overcoming Resistance to Change. Human Relations, 1, 512-532. https://doi.org/10.1177/001872674800100408

Coch, L., \& French, J. (1960). Group Dynamics: Research and Theory.

Communications (2015). Merriam-webster.com. http://www.merriam-webster.com/dictionary/communications

de Andreis, F., \& Carioni, M. (2019). Theoretical Observations on Power in Complex Organizations. American Journal of Industrial and Business Management, 9, 1423-1430. https://doi.org/10.4236/ajibm.2019.96093

Denison, D., Hooijberg, R., Lane, N., \& Lief, C. (2012). Leading Culture Change in Global Organizations: Aligning Culture and Strategy. New York: John Wiley \& Sons.

DeVito, J. A. (2010). Essentials of Human Communication. New York: Pearson Education.

Etzioni, A. (1961). Complex Organizations: A Sociological Reader. New York: Holt, Rinehart and Winston.

Follett, M. P. (1927). Leader and Expert. Dynamic Administration: The Collected Papers of Mary Parker Follett (pp. 320). New York: Harper \& Brothers.

French, J. R., Raven, B., \& Cartwright, D. (1959). The Bases of Social Power. Classics of Organization Theory, 7, 311-320.

Gilbreth, F. B. (1912). Primer of Scientific Management. New York: D. Van Nostrand Company.

Golemon, D., Boyatzis, R., \& McKee, A. (2004). Primal Leadership: Learning to Lead with Emotional Intelligence.

Groves, K., Vance, C., \& Choi, D. (2011). Examining Entrepreneurial Cognition: An Occupational Analysis of Balanced Linear and Nonlinear Thinking and Entrepreneurship Success. Journal of Small Business Management, 49, 438-466.

https://doi.org/10.1111/j.1540-627X.2011.00329.x

Hersey, P., \& Blanchard, K. H. (1969). Management of Organizational Behavior. Englewood Cliffs, NJ: Prentice-Hall.

Hersey, P., Blanchard, K. H., \& Natemeyer, W. E. (2001). Situational Leadership and Power. Classics of Organizational Behavior, 4, 321.

Herzberg, F. (1966). Motivate Employees? World, 88.

Hesselbein, F., \& Goldsmith, M. (2006). The Leader of the Future 2. Soundview Executive Summaries, 28, No. 12.

House, R. J., \& Mitchell, T. R. (1975). Path-Goal Theory of Leadership. Seattle, WA: Washington University.

Kotter, J. P., \& Cohen, D. S. (2002). The Heart of Change: Real-Life Stories of How People Change Their Organizations. Brighton, MA: Harvard Business Press.

Krausz, R. R. (1986). Power and Leadership in Organizations. Transactional Analysis Journal, 16, 85-94. https://doi.org/10.1177/036215378601600202

Lawrence, P. R., \& Lorsch, J. W. (1967). Differentiation and Integration in Complex Organizations. Administrative Science Quarterly, 12, 1-47. https://doi.org/10.2307/2391211

Lewin, K. (1939). When Facing Danger. In G. W. Lewin, Ed., Resolving Social Conflict 
(1948). London: Harper \& Row.

Machiavelli, N., \& Mansfield, H. C. (1998). The Prince. Chicago, IL: University of Chicago Press. https://doi.org/10.7208/chicago/9780226500508.001.0001

Maier, N. R. (1952). Principles of Human Relations: Applications to Management (p. ix474). London: Chapman \& Hall. https://doi.org/10.1037/11194-000

Maier, N. R., \& Hoffman, L. (1960). Quality of First and Second Solutions in Group Problem Solving. Journal of Applied Psychology, 44, 278.

https://doi.org/10.1037/h0041372

Mansfield, H. C. (1998). The Prince.

Maslow, A. H. (1943). A Theory of Human Motivation. Psychological Review, 50, 370. https://doi.org/10.1037/h0054346

McClelland, D. C., \& Burnham, D. H. (1995). Power Is the Great Motivator. Harvard Business Review, 73, 126-139.

Michelson, B. J. (2010). Leadership and Power Base Development: Using Power Effectively to Manage Diversity and Job-Related Interdependence in Complex Organizations. Concepts for Air Force Leadership, 193-199.

Munduate, L., \& Medina, F. J. (2017). Chapter 10 How Does Power Affect Those Who Have It and Those Who Don't? Power Inside Organizations. In An Introduction to Work and Organizational Psychology: An International Perspective (pp. 176-191). New York: Wiley. https://doi.org/10.1002/9781119168058.ch10

Murray, V., \& Gandz, J. (1980). Games Executives Play: Politics at Work. Business Horizons, 23, 11-23. https://doi.org/10.1016/0007-6813(80)90045-2

Ocasio, W., Pozner, J. E., \& Milner, D. (2020). Varieties of Political Capital and Power in Organizations: A Review and Integrative Framework. Academy of Management Annals, 14, 303-338. https://doi.org/10.5465/annals.2018.0062

Page, S. E. (2008). The Difference: How the Power of Diversity Creates Better Groups, Firms, Schools, and Societies. Princeton, NJ: Princeton University Press. https://doi.org/10.1515/9781400830282

Papanek, M. L. (1973). Kurt Lewin and His Contributions to Modern Management Theory. Academy of Management Proceedings, No. 1, 317-322. https://doi.org/10.5465/ambpp.1973.4981410

Peabody, R. L. (1962). Perceptions of Organizational Authority: A Comparative Analysis. Administrative Science Quarterly, 6, 463-482. https://doi.org/10.2307/2390726

Pfeffer, J. (1981). Power in Organizations. Marshfield, MA: Pitman Publishing.

Pfeffer, J. (1992). Managing with Power: Politics and Influence in Organizations. Brighton, MA: Harvard Business Press.

Raven, B. H., \& French Jr., J. R. (1958). Legitimate Power, Coercive Power, and Observability in Social Influence. Sociometry, 21, 83-97. https://doi.org/10.2307/2785895

Raven, B. H., \& Kruglanski, A. W. (1970). Conflict and Power. In The Structure of Conflict (pp. 69-109). New York: Academic Press.

Roethlisberger, F. J. (1941). Management and Morale. Brighton, MA: Harvard University Press. https://doi.org/10.4159/harvard.9780674420540

Salancik, G. R., \& Pfeffer, J. (1978). A Social Information Processing Approach to Job Attitudes and Task Design. Administrative Science Quarterly, 23, 224-253. https://doi.org/10.2307/2392563

Schein, E. H. (1999). Sense and Nonsense about Culture and Climate. Sloan School of 
Management, Cambridge, MA: Massachusetts Institute of Technology.

Schein, V. E. (1977). Individual Power and Political Behaviors in Organizations: An Inadequately Explored Reality. Academy of Management Review, 2, 64-72. https://doi.org/10.5465/amr.1977.4409169

Senge, P. M. (1990). The Fifth Discipline: The Art and Practice of the Learning Organization. New York: Currency Doubleday.

Stacey, R. (1996). Management and the Science of Complexity: If Organizational Life Is Nonlinear, Can Business Strategies Prevail? Research Technology Management, 39, 8-10. https://doi.org/10.1080/08956308.1996.11671056

Tannenbaum, A. S. (1962). Control in Organizations: Individual Adjustment and Organizational Performance. Administrative Science Quarterly, 7, 236-257. https://doi.org/10.2307/2390857

Tworoger, T. M., \& Preziosi, R. C. (2004). Leadership Effectiveness and Power Base Perceptions (pp. 278). New York: Association on Employment Practices and Principles.

Vance, C. M., Groves, K. S., Paik, Y., \& Kindler, H. (2007). Understanding and Measuring Linear-Nonlinear Thinking Style for Enhanced Management Education and Professional Practice. Academy of Management Learning \& Education, 6, 167-185. https://doi.org/10.5465/amle.2007.25223457

Warren, D. I. (1968). Power, Visibility, and Conformity in Formal Organizations. American Sociological Review, 33, 951-970. https://doi.org/10.2307/2092686

Weber, M. (1946). Structures of Power. In Max Weber (pp. 159-179). New York: Oxford University Press.

Zaleznik, A. (1970). Power and Politics in Organizational Life. Harvard Business Review. https://hbr.org/1970/05/power-and-politics-in-organizational-life 